\title{
Repatriation and Reintegration of Cambodian Refugees: Issues and Concerns
}

\author{
Janet McLellan
}

\begin{abstract}
Few countries have been as devastated by war and state abuse as Cambodia. (Asia Watch 1993)

Following more than two decades of war and international isolation, Cambodia is one of the poorest countries in the world. Life expectancy is only 49.7 years. Just 12 per cent of rural Cambodians and 20 per cent of urban dwellers have access to safe drinking water. A relatively large proportion of the population consists of extremely vulnerable groups comprising widows with families, single elderly people, orphans and the disabled. Four of every 1,000 persons are disabled. Women in particular must shoulder heavy burdens and responsibilities. They account for nearly two thirds of the population and head one third of all households (UNRISD 1993:1)
\end{abstract}

\section{Introduction}

In 1991, the United Nations initiated plans for the voluntary repatriation of over $370,000 \mathrm{Khmer}$ refugees to Cambodia. By March 1993, however, four out of the five pre-conditions for repatriation had not met: peace and security, land availability, removal of land mines and long term secured funding (Anderson 1992). The holding of "democratic" elections was the fifth pre-condition.

Though the UNTAC forces were able to implement the May 1993 election procedures, peace and security in Cambodia remained fragile, despite the presence of 20,000 United Nations security forces UNTAC, fighting continued between the Khmer Rouge and State of Cambodia forces resulting in approximately 180,000 internally displaced persons (Ruiz and Robinson 1993). Over forty per cent of farmland remains littered with mines with estimates ranging as high as eight million scattered throughout the country along roads and hillsides (Donavan 1993). Land mines are planted in the country faster than they are being re-

\footnotetext{
Dr. McLellan, a social anthropologist and research associate at Centre for Refugee Studies, is completing a CEIC-funded project on resettlement and integration issues among Cambodian refugees in Ontario. Her publications include studies on Tibetan and Vietnamese refugees in Canada.
}

moved, leaving Cambodia with the highest rate of amputees in the world (Etcheson 1992). Potentially available land remains scarce and equitable allocation procedures have neither been developed nor implemented. Further, adequate funding for long-term rehabilitation, either for returnees or for the country is not forthcoming.

The issues of national security and its effects on development and repatriation have not been resolved. The key element in security is the ability to be free of threat either to the individual and to the nation state (Ayoob 1986). For over 25 years, Cambodia has been in an extreme state of insecurity which has only minimally ebbed as a result of the May 1993 elections. Persistent acts of violence perpetrated by all factions, in particular, by the Khmer Rouge, have not improved the security of country. Between the years, 1975-1979, between one to three million Cambodians were killed, one-quarter of the total population. The Khmer Rouge specifically targeted urban Khmer, ethnic Vietnamese, Muslim Chams, monks, and members of the military and intelligentsia, while numerous others died due to starvation, slave labour, and inhumane living conditions. Political purges also occurred between 1977-1979 within the Khmer Rouge itself giving rise to a new term, autogenocide. The extensive social and individual devastation with its longterm effects raises the question of how the issue of genocide will impact on future development and repatriation concerns.

The spring 1993 election results had the State of Cambodia unifying with the FUNCINPEC faction under the control of Prince Sihanouk's son, Prince Rannaridh, with an aging Prince Sihanouk as the nominal head of state. The Khmer Rouge, who did not participate in the elections, have conceded to the state structure, and it is expected that they will form a part of the new government. It is unclear, however, the extent to which the Khmer Rouge will continue to respect the government's authority and mandate. As well, there is the question of the future relationship between the Khmer Rouge and the people of Cambodia. How the Khmer Rouge will enforce and legitimate their position and the extent of their involvement remains unclear. The UNTAC forces, having completed their mandate, are preparing their departure from Cambodia. The new government will assume power on September 1993. Cambodia's political future remains unpredictable and precarious. Once the UNTAC forces leave, instability and violence could possibly re-emerge on a large scale, with harm to development and repatriation programs in place.

Despite these concerns, an estimated $349,000 \mathrm{Khmer}$ refugees have been repatriated from Thai refugee camps to Cambodia. Due to the scarcity of available agricultural land, ninety per cent of the returnees chose a UNHCR aid package which offered a house/agricultural kit, 400 days of food assistance ( 200 for those settling in Phnom Pehn), and \$50 per adult and $\$ 25$ per child under the age of twelve 
(World Refugee Survey 1993). The destination for the majority of returnees was either Phnom Penh city or Battambang province, an area clustered with mines and surrounded by Khmer Rouge forces engaged in factional fighting.

The urgency and scale of the return of Khmer refugees conformed more to the tight electoral schedule than to any set of objective criteria concerning the conditions they would face in Cambodia (UNRISD 1993:4). UNTAC rationale and expenditures concerned with repatriation led to an excessive emphasis on short-term humanitarian relief aid and insufficient concern for essential forms of development assistance (ibid). In general, the repatriation of Khmer refugees was implemented without an adequate assessment of needs, priorities, resource availability and impacts.

To date, six main development and repatriation concerns have not been addressed:

1. Long-term reintegration programs

2. Reconciliation and healing of past hostilities, in particular, the effects of genocide on the population

3. Damaged and inadequate infrastructures at all levels of government

4. Non-existent institutions to channel or direct foreign aid

5. Economic and environmental exploitation

6. Lack of security within the country hampering successful repatriation.

There is a need to clarify and analyze the major issues of repatriation with particular emphasis on vulnerable groups. As it is not possible to enumerate all of them, three of these issues are briefly addressed.

\section{Distinctions between Refugee Camps}

Repatriated Khmer have come from two distinct types of refugee campsUNHCR holding camps where residents were eligible for resettlement (for example Khao IDang), and border camps which were affiliated with political factions (see Table 1)and operated under the military authority of these factions.
By the end of March 1993, six of the seven border camps had been emptied and closed down. The last camp, Site 2, was officially closed on March 30 though 25,000 refugees have remained there. Apparently, most are expected to repatriate shortly (World Refugee Survey 1993).

The questions remain of where these different groups of returnees have gone, do some have specialized skills gained in particular camps, and are there discernable differences between them?

\section{Age and Skills of Khmer Returnees}

Fifty per cent of the returnee population is less than 15 years old with little or no experience of life outside the refugee camps (Anderson 1992:11). Forty per cent of the returnees are between 15 and 40 years old, with a large segment being 30 to 39 years old (ibid.). Over half their lives have been spent in a combination of slave labour and refugee camp conditions. Further, many of them participated, both actively and under coercion, in the enforcement and enactment of Khmer Rouge policy. They have little experience of living in "normal" Cambodian social settings. Further, as adults, some Khmer have developed education and employment skills in refugee camps under the guidance of Western-based NGOs. Numerous refugees have received technical training, are health service providers (midwives, nurses, medics, doctors), teachers, social workers, community organizers, translators, and administrators. Only about ten per cent of returnees have ever been full time farmers.

Several issues stand out: What will be the integration of the younger Khmer, and how will they develop a sense of security and identity in a country foreign to them? Will they be expected to live and work in rural areas which are unfamiliar to them? Can the over-burdened, ill-equipped and under-funded Cambodian education system integrate large numbers of returnee students, and are there appropriate placement and equivalency tests? Further, is there an evaluation and recognition of vocational and professional skills acquired through training in camps, and are skilled individuals finding employment in their fields? Given their familiarity with various NGOs in the refugee camps, it is possible that returnees will gravitate towards NGOs, either to utilize services or to offer their skills. NGOs may create further obstacles in that a sustained dependency could result from continued services such as food distribution.

Returnees listed numerous areas of work that they wanted to go into when they returned: medical services, teachers, artisans, blacksmiths, barbers, fishermen, rubber plantation workers, miners, factory workers. Can the local economies accommodate these new job-seekers and what effects occur from this competition for scarce positions? As agricultural land becomes available (i.e. cleared of mines), who distributes the land, who is it distributed to and what is the criteria for eligibility-vulnerable groups, local farmers, returnees or internally displaced persons?

\section{Women and Health Concerns}

Seventy-six per cent of the total returnee population are women and children. A large number of the women are sole family supporters. The majority of Khmer women are unedu-

$\begin{array}{ll}\text { Campsite } & \text { Political Auspices } \\ \text { Site K, O'Trao, Site } 8 & \text { Khmer Rouge } \\ \text { Sok Sann, Site 2 } & \text { Son Sann's Khmer People's National } \\ \text { (with }>200,000) & \text { Liberation Front (KPNLF) } \\ \text { Site B } & \text { FUNCINPEC (Prince Sihanouk's faction) } \\ & \text { KPNLF }\end{array}$


cated and illiterate. Further, none of the vocational/technical schools in the refugee camps enrolled women so their lack of skills is a major problem in fitting them into the local economies. Questions remain as to what programs or innovative educational techniques have been designed to meet the special needs of returnee women and what types of assistance or support are they given?

In each refugee camp, Khmer women established a Khmer Women's Association (KWA) and were active in initiating child care, education, literacy, health, counselling and training services for women. Have these women been able to continue both their work and lobbying for women's concerns in Cambodia? Do they receive support either from the government or NGOs and is there potential conflict between their groups and the government backed Women's Association of Cambodia (WAC)?

It is estimated that women account for at least 60 per cent of the adult population in Cambodia and head over one third of all households. Cambodian women bear heavy responsibilities in generating income and producing food while still assuming domestic and child care. Khmer women lack employable skills due to the low levels of education, and do not hold positions of social power and authority.

Several Women In Development programs have been developed in Cambodia to implement social services, health care and life skill and literacy training for women. Will these services and programs be expanded to include returnee women and will the overall mandate of them be suitable to address their particular reintegration needs, social, psychological and physical?

Those refugees who lived in the best-serviced camps would not be prepared for conditions in Cambodia. In all the border camps for example, chlorinated water was supplied and in most camps medical services were eventually regulated and reliable. In Cambodia, however, diarrhoea, mal- nutrition, malaria and tuberculosis remain common ailments and health care treatment is chronically impaired by shortages of drugs, medical supplies and inadequate health care buildings (Anderson 1992).

Highly vulnerable individuals who have been dependent on institutional support structures will find adaptation particularly difficult. These include individuals with physical or mental handicaps, the elderly, orphans, and women who are the sole support for their households. The question remains where these individuals will establish support or receive services: distant family or relatives, local community, pagodas, government or NGOs? Further, how and to what extent are these networks and extended kinships being reconstructed after twenty years?

\section{Summary}

There is obvious need to identify existing infrastructures at community, regional and national levels which can facilitate long-term reintegration and development schemes. It cannot be assumed that infrastructures are functioning, nor can we assume the manner and degree in which infrastructures are being rebuilt. It is this identification which will provide services for integration of the returnees. Further, there is a need to identify local, UNHCR, and international organizations, both government and NGO sponsored, to determine their relationship to returnees, internally displaced refugees, and local Khmer. There is a need to clarify whether programs are being developed specifically for returnees, or whether returnees are somehow expected to fit into organizational agendas for the local Khmer. An extended collection and analysis of material on Cambodian repatriation and development issues is essential to develop policies and guidelines on long-term refugee concerns.

\section{References}

Anderson, Mary B. 1992 "The Repatriation of Cambodian Refugees from Thailand."
Cambridge: The Collaborative for Development Action.

Ayoob, Mohammed. 1986 Regional Security in the Third World: Case Studies from Southeast Asia and the Middle East. Boulder, Colorado: Westview Press.

Asia Watch. 1993 "Cambodia: Human Rights Before and After the Election" Asia Watch 5 (10) May.

Donavan, Paul. 1993 “Opportunity Knocks" in New Internationalist, April 14-18.

Etcheson, Craig. 1992 "The Peace in Cambodia" in Current History Dec. 1992.

Ruitz, Hiram A. and Robinson, Court 1993 World Refugee Survey Washington: U.S. Committee for Refugees.

United Nations Research Institute for Social Development (UNRISD). 1993. "The Social Consequences of the Peace Process in Cambodia." Recommendations and Findings from an UNRISD Workshop. Geneva, Switzerland.April 29-30.

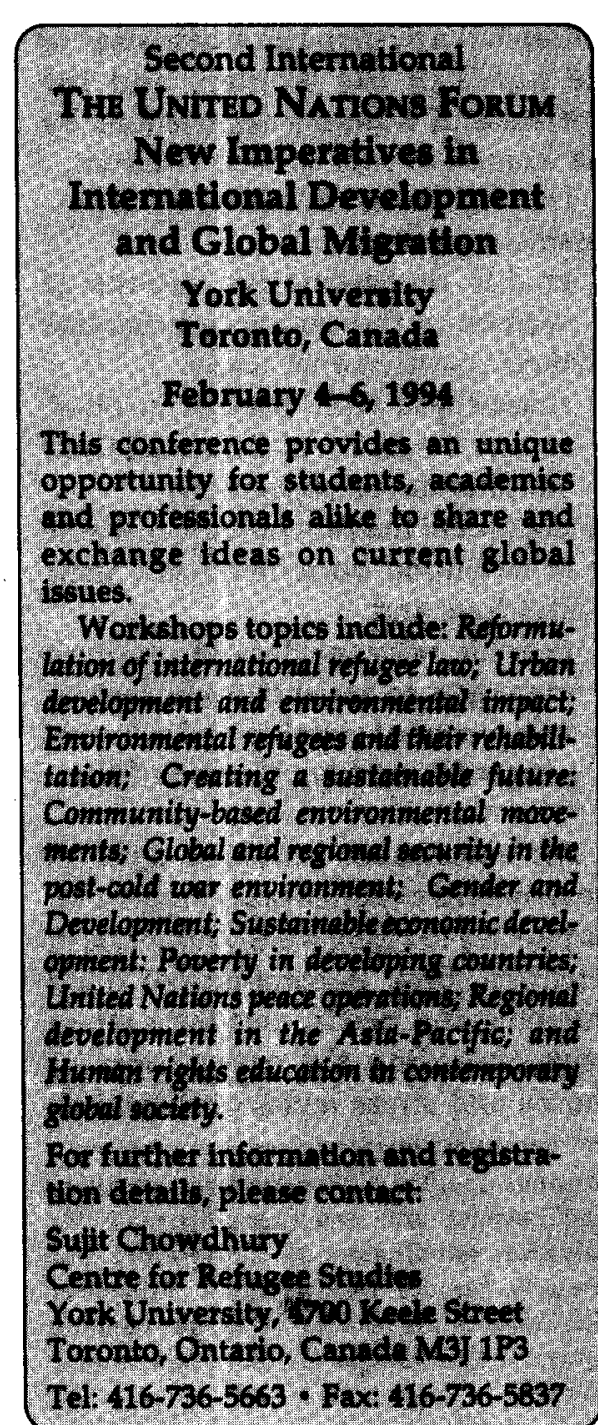

